\title{
Ensino Religioso no Brasil: apontamentos epistemológicos de um modelo em construção
}

\author{
Raimundo Márcio Mota de Castro ${ }^{1}$ \\ José Maria Baldino ${ }^{2}$
}

\begin{abstract}
Resumo
Introduzido na escola como parte da formação do sujeito, o Ensino Religioso tem sido tema de inúmeros debates que vão desde a laicidade do Estado até a sua necessidade como uma disciplina a mais no currículo escolar. Desse modo, este texto tem por objetivo compreender como se tem construído as bases epistemológicas dessa disciplina. Trata-se de uma pesquisa teórico-bibliográfica tendo como aporte Costella (2011), Foucault (1990; 1998; 1999), Horta (1993), Oliveira (2009), entre outros. Percebe-se que a construção epistemológica do Ensino Religioso somente é possível graças ao rompimento da "razão moderna" que possibilitou a multiplicidade dos saberes, tornando-os formas legítimas de conhecimento. Entender o Ensino Religioso como saber formado pela escola e não mais pela religião pode possibilitar ver a religião como fenômeno humano, carregado de subjetividades e diferenças que devem ser respeitadas e entendidas por todos, ao mesmo tempo como instrumento de diálogo com as diferenças.
\end{abstract}

Palavras-Chave: Ensino Religioso; campo; fenômeno religioso.

1 Doutor em Educação pela PUC Goiás. Professor da UEG, Brasil. prof.marciocastro. posgrad@hotmail.com 2 Doutor em Educação pela UNESP. Professor do Programa de Pos-Graduação em Educação da PUC Goiás, Brasil. jmbaldino@uol.com.br 


\title{
Religious education in Brazil: epistemological notes of a model in construction
}

\begin{abstract}
Introduced in school as part of subject formation, Religious Education has been the subject of numerous debates ranging from the secular state until its necessity as a discipline over the school curriculum. Thus, this paper aims to understand how they have built the epistemological foundations of the discipline. This is a search-theoretical literature were supported Costella (2011), Foucault (1990, 1998, 1999), Horta (1993), Oliveira (2009) among others. It is noticed that the epistemological construction of Religious Education, is only possible thanks to the disruption of "modern reason" that enabled the multiplicity of knowledge making them legitimate forms of knowledge. Understand Religious Education as knowing formed by the school but not by religion, can allow to see religion as a human phenomenon, born of subjectivities and differences that must be understood and respected by all at the same time as a tool that can facilitate dialogue with differences.
\end{abstract}

Keywords: religious education; field; religious phenomenon.

\section{Introdução}

Desde o mestrado em Educação, realizado no biênio 2007-2009, tenho voltado minha atenção à investigação do Ensino Religioso na escola pública. Naquele momento, pensei ser uma tarefa fácil investigar o tema. No entanto, logo percebi que isso não passava de desventuras de um pesquisador iniciante. Ao final de minha pesquisa - se é que uma pesquisa pode ter final -, naquela época, uma das conclusões a que cheguei foi que o Ensino Religioso necessitava de uma construção epistemológica para seu entendimento como disciplina do currículo escolar que tem por finalidade a formação integral do ser humano.

Ao fazer a primeira disciplina do doutorado em Educação, na Pontifícia 
Universidade Católica de Goiás (PUC Goiás), denominada Epistemologia e Pesquisa Educacional, ministrada pelo professor doutor José Ternes, entrei em contato com o pensamento de alguns filósofos modernos, entre os quais Michael Foucault; aos poucos, vi acontecer certa desconstrução na forma de como construir a pesquisa educacional, pois, segundo lembrou o professor da disciplina mencionada, em sua fala introdutória:

[...] a ideia da unidade e objetividade do mundo e a sua correlata de um sujeito autônomo e incorruptível somente pode existir numa cultura metafísica, quer dizer, numa cultura que perdeu o sentido e a beleza das coisas, que vê o mundo de longe, representação, imagem, miragem. (TERNES, 2010)

A denominada modernidade, com a promessa de resolver os mais diversos dilemas da vida humana, por meio da razão, não conseguiu dar conta de produzir sentido para a existência. As certezas solidificas deram lugar a muitas incertezas. Isso tudo em decorrência da apropriação e apreensão do conhecimento que se torna mais que uma construção social humana, deslocando sua finalidade: compartilhar o que foi construído e constituído no decorrer da história humana. Agora, a finalidade de conhecer se torna arma, domínio e, sobretudo, poder, como bem lembra Foucault (1999, p. 23):

[...] Ora se quisermos saber o que é o conhecimento, não é preciso nos aproximarmos da forma de vida, de existência, de asceticismo, própria ao filósofo. Se quisermos realmente conhecer o conhecimento, saber o que ele é, apreendê-lo em sua raiz, em sua fabricação, devemos nos aproximar, não dos filósofos mas dos políticos, devemos compreender quais são as relações de luta e de poder. E é somente nessas relações de luta e de poder - na maneira como as coisas entre si, os homens entre si se odeiam, lutam, procuram dominar uns aos outros, querem exercer, uns sobre os outros, relações de poder - que compreenderemos em que consiste o conhecimento.

Ao entender a construção do conhecimento como arma de e para o poder, passei a refletir sobre a epistemologia do Ensino Religioso, compreendendo que esse componente curricular se encontra envolto numa relação de disputa pela sua manutenção, ou seja, numa relação de luta e de poder da qual Foucault acima nos fala. Portanto, o objetivo deste 
trabalho é apontar alguns caminhos à compreensão da epistemologia, ou seja, ao status do conhecimento requerido por essa disciplina, tendo presente que ele se encontra na linha tênue do domínio, em que os homens "procuram dominar uns aos outros" (CASTRO, 2009, p. 35).

Para refletir essa questão, parto dos antecedentes do Ensino Religioso e de como se constituíram e se constituem as relações de luta e de poder em torno dessa disciplina; depois, entendo ser necessário traçar algumas pistas sobre o entendimento do que vem a ser epistemologia; em seguida, busco compreender a finalidade do Ensino Religioso como parte da formação integral do sujeito a partir do entendimento de que essa disciplina privilegie o fenômeno religioso e não mais a doutrina religiosa.

\section{Antecedentes das relações de luta e de poder}

A homogeneização, objetividade e, principalmente, unicidade se apresentam como características marcantes da razão moderna. Tais características contribuem para a formação do etnocentrismo e do monoculturalismo, um grande problema ao homem/mulher contemporâneo, haja vista a exigência atual de uma sociedade capaz de conviver com as diferenças, com a pluralidade de valores, crenças e formas de vida. Ao que parece, essa exigência social hodierna replica e solicita um repensar nos ideais da Renascença, que pretendia "substituir a técnica da prova, característica da lógica clássica, por uma técnica da persuasão" (KOYRÉ, 1982, p. 46), mesmo mantendo a clareza de que, devido a questões de ordem sociológica e histórica, se tenha vivido, na Renascença, uma época fecunda para a crença na magia, na feitiçaria e na superstição (KOYRÉ, 1982).

Porém, ao mesmo tempo em que a Europa experimentava a Renascença, grandes acontecimentos mudaram o rumo da história, entre os quais: as navegações marítimas que possibilitaram o "descobrimento" da América e, posteriormente, o do Brasil; a Reforma protestante que produziu uma "crise" na hegemonia religiosa cristã católica; a Contrarreforma que endureceu os pensamentos eclesiais católicos e reafirmou que esta instituição era a única portadora da verdade; além de muitos outros. 
Eé essa "crise" vivida pela Igreja que nos interessa, uma vez que, graças a ela, o Brasil foi rapidamente tomado por ordens religiosas, entre as quais se destacam os jesuítas, que tinham o intuito de, por meio da educação, aumentar o número de adeptos ao cristianismo católico. A chegada dos religiosos ao Brasil produziu estreita relação entre Igreja e Estado.

Coube à Igreja pensar e efetivar o processo educativo no Brasil durante todo o período Colonial, fato que se prolongou até o início da República. Em que pese o fato dos jesuítas terem sido expulsos do Brasil em 1759 e que o Estado tenha assumido, no final da Colônia e início do Império, a responsabilidade pela educação, o ato de educar permaneceu hegemonicamente sob a coordenação e direção da Igreja, por meio de seus religiosos (bispos, padres, freiras e mesmo leigos formados nos colégios católicos). Desse modo, a educação Brasileira encontrava seu alicerce nos princípios e valores da cristandade católica. Não se questionava a forma e o conteúdo da educação, uma vez que essa função era de exclusividade da família e da Igreja.

As ideias liberais, positivistas, que entraram no Brasil a partir da segunda metade do século XIX, ecoaram nos ideais republicanos e, consequentemente, no advento da República como sistema de governo.

A República, que se instala no Brasil, em novembro de 1889, encontrava a Igreja enfraquecida e incapaz de negociar um novo pacto que viesse a substituir o regime de Padroado e a sua situação de religião oficial do Estado, que lhe havia sido atribuída pela Constituição de 1824. O Estado Republicano rompe com o regime de Padroado e proclama-se leigo. A separação entre Igreja e o estado é oficializada por decreto em janeiro de 1890 e confirmada pela Constituição republicana de 1891. Entre os dispositivos incluídos nessa Constituição, para garantir a plena separação entre a Igreja e o Estado, estava a introdução do ensino leigo nas escolas públicas. (HORTA, 1993, p. 68)

Esse fato marca um tempo de conflito, tendo em uma ponta do "cabo de guerra" a Igreja e de outro o Estado. Tal conflito toma corpo a partir da separação entre a esfera religiosa e esfera pública. Com isso, diversos serviços públicos - o registro de nascimento e óbito, o registro de casamento, a administração de cemitérios e a educação - que, até então, estavam a cargo da Igreja, passam para as "mãos" do Estado. No 
entanto, o ponto nevrálgico estava na educação (SAVIANI, 2008).

Os reformistas republicanos, impulsionados pelos ideais liberais, viam na educação promovida pelo Estado, mas alimentada pela religião, uma conduta incerta para uma sociedade que se pretendia republicana. "Uma das consequências da nova postura foi a introdução do ensino leigo nas escolas públicas, de maneira que a aula de religião foi eliminada" (JUNQUEIRA, 2008, p. 22).

Não caberia à Igreja cuidar e administrar a educação, muito menos caberia à religião estar presente na escola. Tal pensamento encontrou eco na primeira carta constitucional do país, que, no parágrafo $6^{\circ}$, do artigo 72, declara: "Será leigo o ensino ministrado nos estabelecimentos públicos" (BRASIL, 1891). Como lembra Horta (1993), aos poucos a Igreja vai aceitando o regime republicano, uma vez que essa nova ordem possibilitou uma reforma em seus quadros e uma maior ligação com a Cúria Romana. No entanto, para além da eliminação sumária das aulas de religião, surge a reivindicação por uma escola laica, uma vez que a separação entre Igreja e Estado consagra o princípio da laicidade das questões públicas e esse era um ponto de difícil aceitação pelas autoridades eclesiásticas que viam o ensino laico como afronta à fé e à moral cristã, haja vista ser o catolicismo a religião da maioria. Como atesta Beozzo (1984, p. 240 apud HORTA, 1993, p. 68):

[...] consumada a separação entre a Igreja e o Estado, a Igreja não cessará de denunciar o divórcio entre o Estado leigo, para não dizer laicista, e a nação, católica em sua grande maioria. $\mathrm{O}$ ensino, principalmente, era visto como uma grande violência imposta a consciência católica. Seu caráter leigo conflitava com a fé da maioria dos alunos e com a fé professada pela nação. Toda a campanha da Igreja - e ela será constante - estará vazada na luta pelos "direitos" da maioria que deveriam traduzir na legislação e na prática do estado os sentimentos católicos do povo brasileiro.

Os movimentos em torno dessa questão foram inúmeros, os debates acirrados. Após inúmeras investidas, a Igreja conseguiu se aproximar, aos poucos, do governo. Essa aproximação ocorreu preponderantemente a partir da Revolução de 1930, embora a década de 1920 seja marcada por inúmeras estratégias e tentativas de reaproximação da Igreja ao Estado, sem que obtivesse êxito. 
Com a posse de Francisco Campos no recém-criado Ministério da Educação e Saúde e tendo presente seu papel de defensor da religião como valor não somente religioso, mas também como valor de Estado, Dom Leme, arcebispo do Rio de Janeiro, logo se adiantou a enviar a Campos um projeto de decreto que reintroduzisse na escola o ensino de doutrina religiosa. Segundo Horta (1993), após efetuar algumas modificações no projeto original e elaborar uma carta com a exposição de motivos, Campos encaminha o projeto decreto afirmando ao Governo Provisório que tal aprovação seria uma forma de garantir o apoio incondicional da Igreja ao Governo.

A aprovação deste seria, de acordo com Campos, um ato de grande importância, seria talvez o ato de maior alcance político do governo de Getúlio Vargas. Com efeito, no momento em que era, segundo o Ministro, "absolutamente indispensável recorrer ao concurso de todas as forças materiais e morais" a aprovação do decreto de introdução do ensino religioso nas escolas determinaria a mobilização de toda a Igreja Católica ao lado do Governo, empenhando as forças católicas de modo manifesto e declarado, toda a sua valiosa e incomparável influência no sentido de apoiar o governo, pondo ao serviço deste um movimento de opinião de caráter absolutamente nacional. (HORTA, 1993, p. 71)

Considerando os motivos expostos por Campos, Getúlio Vargas não hesita em aprovar, em 30 de abril de 1931, o Decreto n. 19.941, que reintroduziu o ensino de religião na escola. No entanto, tal decreto recebeu várias críticas, principalmente dos intelectuais liberais, que, em 1932, assinaram o Manifesto da Educação Nova, que requeria uma escola pública, gratuita, para todos e, acima de tudo, laica.

No entanto, a Igreja se fortalecia e elaborava estratégias para pressionar e se aproximar cada vez mais do governo. As pressões foram tantas, a ponto de conseguir introduzir na Constituição Federal de $1934^{3}$ um artigo que garantisse a permanência do ensino de religião na escola; no entanto, para amenizar as críticas, a nomenclatura utilizada passa a ser de Ensino Religioso. Como bem lembra Foucault (1998, p. 10): “A história não cessa de nos ensinar - o discurso não é simplesmente aquilo

3 Art. 153 - O Ensino Religioso será de frequência facultativa e ministrado de acordo com os princípios da confissão religiosa do aluno manifestada pelos pais ou responsáveis e constituirá matéria dos horários nas escolas públicas primárias, secundárias, profissionais e normais (BRASIL, 1934). 
que traduz as lutas ou os sistemas de dominação, mas aquilo por que se luta, o poder do qual nos queremos apoderar".

Percebendo e entendendo sua força política, a Igreja conseguiu se mobilizar e manter o Ensino Religioso nos documentos legislativos brasileiros, tendo inclusive o privilégio de manter esse componente curricular como o único garantido constitucionalmente em todas as Constituições Brasileiras, desde 1934 e, ainda, nas Leis de Diretrizes e Bases da Educação Nacional. Fato importante de evidenciar é a primeira alteração da Lei n. 9.394 (LDB 96), que, após seis meses de sua promulgação, teve o artigo 33 alterado, uma vez que a redação anterior não satisfazia os interesses dos grupos religiosos, especialmente os da Igreja Católica. Segundo Pauly (2004), foi “o lobby eclesiástico que aprovou a lei no 9.475/97, alterando o art. 33 da Lei de Diretrizes e Bases da Educação Nacional (LDBEN)".

Cabe, portanto, uma pergunta: qual a epistemologia produzida e que produz esse componente curricular? Numa tentativa de encontrar uma resposta, primeiramente, entendo ser preciso compreender o que é isso: a epistemologia.

\section{Apontamentos sobre epistemologia}

A palavra epistemologia se compõe da junção de duas palavras gregas: episteme (ciência, saber) e logos (teoria, palavra, razão) (OLIVEIRA, 2009); nesse sentido, é possível entender que se trata de um discurso sobre o saber, ou seja, sobre o conhecimento. Abbagnano (1998, p. 183) apresenta as variações e os usos da palavra em diversos idiomas e infere que a palavra epistemologia é entendida por seu sinônimo "gnosiologia" ou teoria do conhecimento; no entanto, mesmo considerando seus diversos usos, o autor alerta: “Todos esses nomes têm o mesmo significado: não indicam, como muitas vezes se crê ingenuamente, uma disciplina filosófica geral, como a lógica, a ética ou a estética, mas um modo de tratar um problema nascido de um pressuposto filosófico específico [...]" (ABBAGNANO, 1998, p. 183).

Mas Japiassu e Marcondes (2006, p. 67-68) são categóricos ao afirmar que se trata de uma disciplina que: 
[...] toma as ciências como objeto de investigação tentando reagrupar: a) a crítica do conhecimento científico (exame dos princípios, das hipóteses e das conclusões das diferentes ciências, tendo em vista determinar seu alcance e seu valor objetivo); b) a filosofia das ciências (empirismo, racionalismo etc.); c) a história das ciências [...] Em outras palavras ela se interessa pelo problema do crescimento dos conhecimentos científicos. Por isso, podemos defini-la como a disciplina que toma por objeto não mais a ciência verdadeira de que deveríamos estabelecer as condições de possibilidade ou os títulos de legitimidade, mas as ciências em via de se fazerem, em seu processo de gênese, de formação e de estruturação progressiva. (grifo nosso)

No mesmo sentido desses autores, Oliveira (2009, p. 16) afirma:

Epistemologia é a ciência que estuda o fundamento, a extensão, o grau, os limites, as possibilidades, as condições, o alcance, a constituição, a sustentação, a concatenação das ideias, a veracidade, a justificação, a certeza e a evidência presentes ou não num determinado conhecimento.

Nesse sentido, é possível afirmar que a epistemologia tem sua gênese na reflexão sobre o fundamento de uma afirmação, ou seja, na resposta à questão: "como se sabe isso sobre algo?". Seria como submeter o conhecimento a um inquérito, sem o qual o conhecimento não consegue se estabelecer. Foucault (1999), ao investigar a formação do domínio do saber a partir de práticas sociais, propõe duas histórias da verdade. $\mathrm{Na}$ primeira história, reside o inquérito como forma "bem característica da verdade em nossas sociedades" (FOUCAULT, 1999, p. 12). Ainda segundo esse autor: "[...] Foi para saber exatamente quem fez o quê, em que condições e em que momento, que o Ocidente elaborou as complexas técnicas do inquérito que puderam, em seguida, ser utilizadas na ordem científica e na ordem filosófica" (FOUCAULT, 1999, p. 12).

Mas como surge a epistemologia? Bem, ao entendê-la como a parte da filosofia que tem por finalidade o entendimento da questão do conhecimento (origem, método, estrutura, validade), é lícito localizála na Antiguidade Clássica, principalmente nos escritos de Platão que tratam da origem do conhecimento verdadeiro (no qual destaco Segundo Alcebíades e Teeteto) e nos escritos de Aristóteles (Organun, De Anima). Penso que esse seja o motivo de prevalecer em alguns idiomas a opção 
pela gnosiologia ou teoria do conhecimento para também designar a epistemologia.

No entanto, ao entender a epistemologia como parte da construção do pensamento moderno, o marco referencial seria tanto a obra Ensaio acerca do entendimento humano ${ }^{4}$, do filósofo John Locke (1632-1704), na qual o inglês estabelece os princípios da epistemologia; quanto as obras de Immanuel Kant (1724-1804) - Crítica da razão pura, Crítica da razão prática e Crítica da faculdade do juízo, o autor elabora uma síntese do racionalismo e do empirismo e se preocupa com a gênese do conhecimento - sobre como surge o conhecimento, mas com sua validade lógica, ou seja, sobre como é possível o conhecimento, quais seus alicerces e sobre quais pressupostos se assenta. Entrava em curso a rigidez da racionalidade moderna.

No final do século XIX e na primeira metade do século XX, um grupo de pensadores, que ficou conhecido como Círculo de Viena (1922-1938), formula o positivismo lógico com o objetivo de desenvolver uma linguagem desprovida de ambiguidades e que servisse de forma exemplar ao conhecimento científico, ou seja, uma “[...] filosofia antimetafísica, estreitamente ligada às ciências da natureza, à lógica e à matemática" (LACOSTE, 1992, p. 128). Essa escola permite entender a epistemologia como "teoria do conhecimento".

Em contraste com o paradigma epistemológico do positivismo lógico, surgem duas novas correntes de pensamento que pretendem superar a "forte racionalidade instrumental" da modernidade. De acordo com Lacoste (1992), a primeira reside no campo do conhecimento físico/ matemático, com a teoria da relatividade de Einstein, o surgimento da física quântica e o princípio de indeterminação de Heisenberg; e a segunda reside no campo da filosofia, a partir da publicação da obra póstuma de Husserl, intitulada A crise das ciências europeias e a filosofia, na qual o autor apresenta os possíveis perigos da razão puramente instrumental.

Tais mudanças na forma de pensar possibilitam admitir a pluralidade de saberes, uma vez que até o saber mais puro e rigoroso, como o das ciências exatas, apresenta-se incapaz de autofundação, ou seja, de possuir em si sua causa e efeito; com isso, supera-se o modo linear e causal de conhecer e se começa a pensar em termos de interdependência e 
circularidade. Ao superar a dicotomia ciências naturais/ciências humanas, sujeito/objeto, passa-se a integração homem-natureza, percebendo que ambos possuem uma interdependência e continua circularidade.

Uma epistemologia ancorada na razão instrumental impossibilitava que a religião fosse passível de conhecimento, uma vez que seu objeto não se apresentava palpável, situação que limitava a visão do sujeito. Compreendendo a superação da dicotomia homem/natureza, sujeito/ objeto, a religião passa a ser entendida como fenômeno passível de ser conhecido, ainda que construído ou inato ao homem.

E isso só é possível pelo fato de que:

[...] não há uma natureza do conhecimento, uma essência do conhecimento, condições que não são da ordem do conhecimento. $\mathrm{O}$ conhecimento é um efeito ou um acontecimento que pode ser colocado sob o signo do conhecer. O conhecimento não é uma faculdade, nem uma estrutura universal. Mesmo quando utiliza um certo número de elementos que podem passar por universais, esse conhecimento será apenas da ordem do resultado, do acontecimento, do efeito. (FOUCAULT, 1999, p. 24)

Ao pensar o conhecimento nessa perspectiva apresentada por Foucault, que retoma o pensamento elaborado por Nietzsche, já se encontra uma epistemologia, ou seja, um discurso sobre o próprio conhecimento. Como se pode notar, a epistemologia não terá uma única forma de entender o conhecimento, mas, se desdobrará em diversos entendimentos, e isso não diminuiu o valor real da ciência, o que se possibilita é um deslocamento do valor da verdade, que deixa de ser dogmático e definitivo para se tornar provisório, dado a variedade de discursos sobre o próprio conhecimento e sobre a ciência.

Portanto, conceituar a epistemologia não se torna tarefa fácil, uma vez que, ao relacionar o termo ao discurso sobre a ciência e que a ciência é um tipo de saber, e não o saber único e definitivo. Nesse sentido, vale, pois, o alerta de Japiassu (1979, p. 39-40):

O conceito de epistemologia é, pois, empregado de modo bastante flexível. Segundo os autores, com seus pressupostos filosóficos ou ideológicos, e em conformidade com os países e os costumes, ele serve para designar, quer uma teoria geral do conhecimento (de natureza mais ou menos filosófica), quer estudos mais restritos 
interrogando-se sobre a gênese e a estrutura das ciências, tentando descobrir as leis de crescimento dos conhecimentos, quer uma análise lógica da linguagem científica, quer, enfim, o exame das condições reais de produção dos conhecimentos científicos. Qualquer que seja a acepção que dermos ao termo "epistemologia", a verdade é que ela não pode e nem pretende impor dogmas aos cientistas. Não pretende ser um sistema, a priori, dogmático, ditando autoritariamente o que deveria ser o conhecimento científico. Seu papel é o de estudar a gênese e a estrutura dos conhecimentos científicos. Mais precisamente, o de tentar pesquisar as leis reais de produção desses conhecimentos. E ela procura estudar esta produção dos conhecimentos, tanto do ponto de vista lógico, quanto dos pontos de vista linguístico, sociológico, ideológico, etc. Daí seu caráter de disciplina interdisciplinar. E como as ciências nascem e evoluem em circunstâncias históricas bem determinadas, cabe à epistemologia perguntar-se pelas relações existentes entre a ciência e a sociedade, entre a ciência e as instituições científicas, entre as diversas ciências, etc.

Neste trabalho, porém, considero a epistemologia, com base em Japiassu (1979), não como ciência, mas como saber. Para esse autor, "pode-se utilizar o termo 'saber' para designar uma série de disciplinas intelectuais mais ou menos estabelecidas, mas que não podem ser consideradas como ciências"' (p. 16). Nesse sentido, por epistemologia, pode-se "considerar o estudo metódico e reflexivo do saber, de sua organização, de sua formação, de seu desenvolvimento, de seu funcionamento e de seus produtos intelectuais" (p. 17).

Por fim, ao optar pelo entendimento de uma epistemologia do Ensino Religioso, tenho presente que:

Antes do surgimento de um saber ou de uma disciplina científica, há sempre uma primeira aquisição ainda não científica de estados mentais já formados de modo mais ou menos natural ou espontâneo. No nível coletivo, esses estados mentais são constitutivos de uma certa cultura. Eles constituem as "opiniões primeiras" ou pré-noções, tendo por função reconciliar o pensamento comum consigo mesmo, propondo certas explicações. Podemos caracterizar tais pré-noções como um conjunto falsamente sistematizado de juízos, constituindo representações esquemáticas e sumárias, formadas pela prática e para a prática, obtendo sua evidência e sua "autoridade" das funções sociais que desempenham. (JAPIASSU, 1979, p. 17-18) 
Foi tendo presente essa realidade que Foucault (1990), em As palavras e as coisas, tece uma "arqueologia" das ciências humanas, ou seja, busca uma objetivação do sujeito no campo dos saberes, que tem um caráter histórico e político, procurando descobrir como os saberes aparecem e se transformam.

Após apontar pistas sobre a epistemologia e localizá-la neste texto como saber, parto para entender os problemas advindos da constituição do Ensino Religioso como saber presente na escola.

\section{Ensino Religioso: saber integrante da formação}

Como já observado anteriormente, nos primeiros anos da República (entre a primeira e a segunda Constituição Federal - 1891/1934), em que pese as pressões e os debates acirrados entre os republicanos defensores da laicidade e o os católicos, teve-se um período efetivo, ao menos na legislação brasileira, do caráter laico do Estado. Com a Constituição de 1934, o ensino da religião retoma seu lugar na escola, possuindo novo nome - Ensino Religioso -, mas impregnado de velhas práticas.

Utilizando-se do argumento de a fé católica ser professada pela maioria da população, a Igreja tomou a frente desse ensino. No entanto, as visões e entendimentos desse ensino foram sendo modificadas aos poucos, ou seja, seus saberes, contingenciados pelo tempo e pela cultura, foram sendo modificados. Isso se pode notar no próprio percurso das três leis ${ }^{5}$ que regulamentaram o ensino nacional.

Na Lei n. 4.024/61, havia um ponto de vista teológico, confessional, doutrinal e esse ensino era ministrado como extensão da confessionalidade católica, pois seu eixo articulador era a dimensão do saber em si (religere $=$ re-escolher). Com a promulgação da Lei n. 5.692/71, tem-se o oferecimento de uma disciplina interconfessional, levando em consideração os aspectos antropológico e axiológico da disciplina. Nesse sentido, a disciplina já não é uma exclusividade dos católicos, outros credos passam a ser legítimas instâncias para ministrar tais aulas. A

5 Menciono três leis nacionais do ensino, uma vez que considero a Lei n. 5.692/71, como uma lei que estabeleceu as diretrizes impostas pelo regime militar à educação, mesmo tendo consciência que não se trata efetivamente de uma lei de diretrizes e bases. 
dimensão norteadora dessa perspectiva se centra no saber em si (re-ligare $=$ re-ligar). Por fim, a Lei n. 9.394/96 passa a privilegiar a dimensão do saber em si, mas numa perspectiva diferente da confessionalidade (relegere $=$ re-ler); nessa nova forma de ministrar a disciplina, o que se deve levar em consideração é a religião como fenômeno humano, ou melhor, como experiência humana diversa. Sobre esse entendimento, Oliveira et al. (2007, p. 102) destaca: “o objeto do Ensino Religioso é o fenômeno religioso, assumindo a conceituação de religião dada pelo latim religio, na forma de sua derivação: relegere, que em português significa 'reler'". Ainda segundo os autores:

A religião pode auxiliar o ser humano a definir-se no mundo e em relação a seus semelhantes e emprestar-lhe um sentido de vida. Constitui uma fonte de informações para seus fiéis e orienta-os, em suas ações, em questões relacionadas à origem, destino e sentido da existência. Ela também pode fornecer respostas ás ameaças que pesam sobre toda a vida dos seres humanos. Com essa compreensão, o Ensino Religioso na escola brasileira propõe estudar e interpretar o fenômeno religioso com base no convívio social dos alunos, constituindo-se objeto de estudo e conhecimento na diversidade cultural-religiosa do Brasil. (OLIVEIRA et al., 2007, p. 103)

Desse modo, estabelece-se um novo paradigma na oferta do Ensino Religioso para escola pública, que passa a ser entendido como campo de conhecimento e de formação cultural. É nesse sentido que seu caráter passa a ser necessariamente universal, propondo o respeito a todos os tipos de religião sem discriminação ou privilégio a nenhuma delas. No entanto, é necessário ressaltar que ainda se trata de uma disciplina que gera inúmeras opiniões e controvérsias sobre sua permanência e necessidade na escola como parte da formação do cidadão.

O estabelecimento do Ensino Religioso como disciplina e área do conhecimento se encontra ancorado na epistemologia contemporânea da complexidade, ${ }^{6}$ que privilegia a multiplicidade de sentidos e de entendimentos, ou seja, a unitas multiplex ("unidade múltipla"). É justamente a partir dessa nova visão epistemológica que o Ensino

6 A teoria da complexidade foi elaborada pelo epistemólogo e sociólogo francês Edgar Morin. Em sua obra A religação dos saberes: o desafio do século XXI, o autor propõe a reforma do pensamento e a reconstrução dos saberes como via prioritária para compreender e gerir a complexidade (COSTELLA, 2011). 
Religioso passa a se construir como disciplina escolar, uma vez que passa a ser uma construção escolar e não mais um discurso religioso.

Entendendo essas mudanças epistemológicas e afirmando que a religião é um universo de significação, uma vez que provoca o humano a uma (re)leitura e (re)interpretação do mundo, do homem e da transcendência, Costella (2011, p. 135) traça alguns indicadores que podem ser vistos, inclusive no texto da LDB:

[...] a) o Ensino Religioso é parte integrante da formação básica do cidadão, b) no Ensino Religioso deve ser assegurado o respeito á diversidade cultural e religiosa da formação da nacionalidade brasileira, c) no Ensino Religioso ficam vedadas quaisquer formas de proselitismo, d) o Ensino Religioso é disciplina do ensino fundamental, nasce o problema/desafio: enfocar o Ensino Religioso como "disciplina" escolar (estamos, portanto, tratando de conhecimento e não de crença e de fé-teologia), ao mesmo tempo colocando-o na perspectiva pedagógica da escola, de maneira que possa cumprir o seu papel específico, em ligação com os outros saberes e formas de conhecimento para a formação do aluno(a).

Nesse sentido, também como complementa o autor, "trata, na verdade, de superar a tradicional 'aula' de Religião, que era muito mais catequese e doutrinação, com o perigo de intolerância com relação a outros credos e abrir a perspectiva de verdadeiro ensino" (COSTELLA, 2011, p. 135). Ou seja, nessa perspectiva, cabe ao Estado, à sociedade e à escola considerar o Ensino Religioso como componente curricular que tem por conteúdo o fenômeno religioso e suas diversas nuances. Percebo que essas instâncias institucionais têm entendido esse ensino ora como uma formação religiosa, ora como formação de ordem catequética e de ação pastoral.

Diante do exposto, é lícito perguntar: a que ciência pertence o saber religioso? Que tipo de saber é o religioso? Qual seu objetivo específico? Costella (2011, p. 136) ajuda nesse entendimento:

O estudo da religião faz parte das ciências humanas (antropológicohistórico- culturais). Religião é fenômeno produzido pelas sociedades humanas, situadas em contextos histórico-geográficos diferentes, para responder às questões fundamentais da existência humana, no seu aspecto de limite, mas também anseio de transcendência: "o homem é o único ser que recusa a ser aquilo que é" (CAMUS, 1996, p. 21-22). Portanto, o objeto específico 
do Ensino Religioso é o fenômeno e/ou fato religioso, como se expressam em seus símbolos, crenças, instituições, personagensfundadores, textos sagrados, códices morais, cosmovisões acerca do mundo, da vida, da morte do futuro.

Segundo o autor, o Ensino Religioso teria a finalidade de apresentar os diversos fenômenos religiosos, ou seja, as possibilidades que, culturalmente, foram sistematizadas pelas sociedades para responder ao anseio do sagrado. Diante disso, cabe uma pergunta: como fica os que não creem? Entendo que é da experiência religiosa que nasce a possibilidade de não crer, uma vez que foi necessário, primeiramente, o ser humano se apresentar como ser que acredita e, a partir de outra experiência, ser conduzido a pensar outra possibilidade: a recusa da fé.

Caberia, então, ao Ensino Religioso apresentar o crer e o não crer como possibilidades epistemológicas, pois não ter fé num ente transcendente não significa dizer que a pessoa seja desprovida de fé. Pode-se crer em outras coisas. E isso também serve para a crença, uma vez que não há uma única forma, um único deus, ou um único sistema religioso. Nesse sentido, penso residir o Ensino Religioso como parte da formação integral do sujeito, conduzindo-o a pensar as diferenças, a complexidade social em que vivemos e que nos faz diferentes, mas ao mesmo tempo iguais em nossas buscas, em nossa construção como seres históricos. Por isso, o Ensino Religioso tem a necessidade de ser construído a partir da fenomenologia da religião. Ao entender cada religião como fenômeno e não como o fenômeno, pode-se construir uma consciência antifundamentalista, uma vez que:

[...] o fundamentalismo é a resposta errada a uma situação epistêmica, que impinge a compreensão que a tolerância religiosa é inelutável; com isso ele sobrecarrega os fiéis, que têm que enfrentar a secularização do saber e o pluralismo das cosmovisões, sem deixar que afetem as próprias verdades de fé. (HABERMAS, 2003, p. 201-202 apud COSTELLA, 2011, p. 130)

Portanto, pode-se compreender o Ensino Religioso dentro de uma pluralidade dos saberes - inclusive educacionais - preconizados na própria LDB de 1996, que afirma que a educação é uma construção que ocorre em todos os ambientes e, por isso, deve ter a preocupação 
de formar o sujeito, tanto para o trabalho quanto para a cidadania. Ao entender que o Ensino Religioso pode auxiliar na formação da consciência cidadã, não tenho em mente a cidadania apenas como principio de inclusão e igualdade, mas a entendo como "base da pertença humana, sobre o estatuto da pessoa" (COSTELLA, 2011, p. 134).

Como afirma Guerreiro (2006, p. 21):

Todas as religiões estão enraizadas em uma dada sociedade e são expressões das visões de mundo e da maneira de viver de grupos sociais concretos. Nesse sentido, não podemos dizer que existam verdadeiras ou religiões falsas. Afirmações dessa natureza têm contribuído para muitas desavenças entre povos, levando, às vezes, à segregação ou até mesmo a guerras e alimentando o ódio, muitas vezes presente, contra as seitas em geral. Por mais estranhas ou exóticas que possam parecer, todas as formas religiosas são coerentes com o modo de vida de um povo.

Desse modo, o Ensino Religioso deve ser pensado na perspectiva do "aprender a aprender" o fenômeno religioso presente nas diferentes sociedades e culturas religiosas, tendo presente que a escola é lócus privilegiado do encontro das diversidades sociais e religiosas. "Nessa diversidade inclui-se o ser humano como um ser que precisa ser respeitado pelas suas diferenças, tais como radical, social, cultural e religiosa" (HOLMES, 2010, p. 50).

\section{Considerações finais}

A Lei n. 9.475, de 22 de julho de 1997, que deu nova redação ao artigo 33 da Lei n. 9.394, de 20 de dezembro de 1996, apresenta grandes avanços na possibilidade da oferta do Ensino Religioso na escola. Em que pese as críticas, essa lei possibilita que as o Ensino Religioso seja tratado como disciplina escolar e não como parte da doutrinação e catequese das diversas denominações majoritárias em detrimento dos grupos com menor representatividade.

Nesse sentido, a construção de uma epistemologia que constitua os saberes dessa disciplina é função da escola como lócus de sua efetivação e da academia como lócus de produção e reflexão do conhecimento. Cabe às diversas religiões apenas participação, como entidade civil, 
na definição dos conteúdos e não mais "a definição" desses conteúdos e o credenciamento dos professores, como acontecia anteriormente; inclusive, ao apontar Estados e Municípios como responsáveis pelo credenciamento dos professores, a lei demonstra a preocupação com a laicidade do Estado e o respeito às diferenças.

Se não está evidente uma epistemologia que sustente o Ensino Religioso, entendo ser pelo motivo de que poucos teóricos da educação tenham se debruçado sobre a questão, apesar de que em diversas áreas ele seja profícuo. Entendo que a ausência de debates tem permitido que o espaço/tempo da disciplina seja praticado em modelos coloniais: como pregação e repasse de uma verdade única de fé, fato que não contribui para a construção de uma sociedade plural.

Ao entender o fenômeno religioso como objeto do Ensino Religioso, tem-se presente que essa disciplina não diz respeito a conhecimento teológico das diversas igrejas, mas que o saber religioso é uma construção social e antropológica, situação que possibilita entender também a ausência de necessidade da busca do transcendente por parte dos que não professam nenhuma fé religiosa.

Como se pode perceber, apesar das tentativas empreendidas, não se pode falar de uma epistemologia do Ensino Religioso, mas de tentativas de construção a partir do modelo da metaconfessionalidade, ou seja, na construção de um objeto de estudo que se contraponha ao modelo confessional ou interconfessional que tem sido praticado na escola. No entanto, isso só será possível mediante o estudo e o aprofundamento do tema.

No entanto, fica uma questão em aberto: em tempos de defesa da reaglutinação das disciplinas, que se coloca frente à fragmentação do saber e do sujeito, seria possível a construção de mais um saber no currículo escolar? O desafio está posto e longe de ser concluído, espera-se que tais questionamentos, abertos e latentes, possam suscitar o interesse pelo tema, principalmente por parte dos que militam na árdua tarefa de ensinar. 


\section{Referências}

ABBAGNANO, Nicola. Dicionário de Filosofia. São Paulo: Martins Fontes. 1998.

ARISTÓTELES. Tópicos; Dos argumentos sofísticos. Tradução de Leonel Vallandro e Gerd Bornheim da versão inglesa de W.A. Pickard. São Paulo: Nova Cultural, 1987.

ARISTÓTELES. Obras completas: De Anima. Trad. Ana Maria Lobo. Centro de Filosofia da Universidade de Lisboa. Lisboa: Imprensa Nacional-casa da moeda, 2010.

BRASIL. Constituição da República dos Estados Unidos do Brasil, 24 de Fevereiro de 1891. Brasília, DF: Diário Oficial da União, 24 fev. 1891. Disponível em: <http://www.

planalto.gov.br/ccivil_03/constituicao/constituicao91.htm>. Acesso: 10 dez. 2011.

BRASIL. Constituição da República dos Estados Unidos do Brasil, 16 de julho de 1934. Brasília, DF: Diário Oficial da União, 16 jul. 1934. Disponível em: <http://www.planalto. gov.br/ccivil_03/constituicao/constituicao34.htm>. Acesso: 5 dez. 2011.

BRASIL. Decreto n ${ }^{0} 19.941$, de 30 de abril de 1931. Dispõe sobre a instrução religiosa nos cursos primário, secundário e normal Disponível em: <http:/ / www2.camara.leg.br/legin/fed/ decret/1930-1939/decreto-19941-30-abril-1931-518529-norma-pe. html> Acesso: 20 abr. 2013.

BRASIL. Lei n. 4.024, de 20 de dezembro de 1961. Fixa as Diretrizes e Bases da Educação Nacional. Disponível em: <http:/ / wwwp.fc.unesp. br/ lizanata/LDB\%204024-61.pdf> Acesso: 10 abr. 2012. 
BRASIL. Lei n. 5.692, de 11 de agosto de 1971. Fixa as Diretrizes e Bases para o ensino de $1^{\circ}$ e $2^{\circ}$ graus. Disponível em: <http:/ / www. planalto.gov.br/ccivil_03/leis/15692.htm> Acesso: 12 abr. 2012.

BRASIL. Lei n. 9.394, de 20 de dezembro de 1996. Estabelece as diretrizes e bases da educação nacional. Brasília, DF: Diário Oficial da União, 23 dez. 1996. Disponível em: <http://www.planalto.gov.br/ ccivil_03/leis/19394.htm>. Acesso: 10 abr. 2013.

BRASIL. Lei n. 9.475, de 22 de julho de 1997. Dá nova redação ao art. 33 da Lei n. 9.394, de 20 de dezembro de 1996, que estabelece as diretrizes e bases da educação nacional. Brasília, DF: Diário Oficial da União, 23 jul. 1997. Disponível em: <http:/ / www.planalto. gov.br/ccivil_03/Leis/19475.htm>. Acesso: 10 abr. 2013.

COSTELLA, Domenico. O fundamento epistemológico do Ensino Religioso. In: JUNQUEIRA, Sérgio Rogério de Azevedo; WAGNER, Raul (Org.). O Ensino Religioso no Brasil. 2. ed. ver. e ampl. Curitiba: Champagnat, 2011. p. 129-142.

FOUCAULT, Michael. As palavras e as coisas: uma arqueologia das Ciências Humanas. São Paulo, SP: Martins Fontes, 1990.

FOUCAULT, Michael. A ordem do discurso. São Paulo: Loyola, 1998.

FOUCAULT, Michael. As verdades e as formas jurídicas. 2. ed. Rio de Janeiro: Nau Editora, 1999.

GUERREIRO, Silas. Novos movimentos religiosos: o quadro brasileiro. São Paulo: Paulinas, 2006.

HOLMES, Maria José Torres. Ensino Religioso: problemas e desafios. 2010. 187 f. Dissertação (Mestrado em Ciências da Religião) Universidade Federal da Paraíba, João Pessoa, 2010. 
HORTA, José Silvério Baia. O Ensino Religioso na Itália fascista e no Brasil (1930-45). Educação em Revista, Belo Horizonte, n. 17, p. 64-78, jun. 1993.

HUSSERL, Edmund. A crise da humanidade europeia e a filosofia. Trad. Urbano Zilles. 2. ed. Porto Alegre: EDIPUCRS, 2002.

JAPIASSU, Hilton. Introdução ao pensamento epistemológico. Rio de Janeiro: Francisco Alves, 1979.

JAPIASSU, Hilton; MARCONDES, Danilo. Dicionário básico de filosofia. 4 ed. Rio de Janeiro: Jorge Zahar Ed., 2006.

JUNQUEIRA, Sérgio Rogério Azevedo. História, legislação e fundamentos do Ensino Religioso. Curitiba: IBPEX, 2008.

KANT, Immanuel. Crítica da razão prática. São Paulo: Martins Fontes, 2003.

KANT, Immanuel. Crítica da razão pura: outros Textos Filosóficos. Tradução de Valério Rohden e Udo Baldur Moosburger. 3. ed. São Paulo: Abril Cultural, 1987. Coleção Os Pensadores.

KANT, Immanuel. Crítica da Faculdade do juízo. Tradução de Valério Rohden e Antônio Marques. 2. ed. Rio de Janeiro: Forense Universitária, 2002.

KOYRÉ, Alexandre. A contribuição científica da Renascença. In: KOYRÉ, Alexandre. Estudos de história do pensamento científico. Rio de Janeiro: Ed. Forense Universitária; Brasília: Ed. Universidade de Brasília, 1982. p. 46-55.

LACOSTE, Jean. A Filosofia no século XX. Campinas,SP: Papirus, 1992.

LOCKE, Jonh. Ensaio acerca do entendimento humano. São Paulo: Nova 
Cultural, 1999. Coleção "Os pensadores".

MORIN, Edgar. A religação dos saberes: o desafio do século XXI. Trad. Flavia Nascimento. Rio de Janeiro: Bertrand Brasil, 2001.

OLIVEIRA, Edmilson Turozi. Ensino Religioso: fundamentos epistemológicos. Curitiba: IBPEX, 2009.

OLIVEIRA, Lilia Blanck et al. Ensino Religioso no ensino fundamental: fundamentos e métodos. São Paulo: Cortez, 2007.

PAULY, Evaldo Luis. O dilema epistemológico do Ensino Religioso. Revista Brasileira de Educação, São Paulo: ANPEd, n. 27, p. 172-182, set./out./nov./dez. 2004. Disponível em: <http://www.anped.org. br/rbe27/anpedn27-art11.pdf>. Acesso: 5 set. 2011.

PLATÃO. Alcibíades I e II. Trad. e introdução de F. L. Vieira de Almeida. Lisboa: Inquérito, s/d.

PLATÃO. Diálogos V: Parmênides, Teeteto, Sofista, Político. Traduções, introduções e notas por Isabel Santa Cruz (Parmênides e Político), Álvaro Vallejo Campos (Teeteto), Nestor Luis Cordero (Sofista). Traducciones revisadas e asesor para la sección griega por Carlos Garcia Gual. Madrid,España: Editorial Credos,1988.

SAVIANI. Dermeval. História das ideias pedagógicas no Brasil. 2. ed. ver. ampl. Campinas, SP: Autores Associados, 2008.

TERNES, José. Introdução à disciplina Epistemologia e Pesquisa Educacional. Goiânia: Pontifícia Universidade Católica de Goiás, 2010. (mimeo) 